\title{
Learning to Love Globalization: Education and Individual Attitudes Toward International Trade
}

\author{
Jens Hainmueller and Michael J. Hiscox
}

\begin{abstract}
Recent studies of public attitudes toward trade have converged on one central finding: support for trade restrictions is highest among respondents with the lowest levels of education. This has been interpreted as strong support for the StolperSamuelson theorem, the classic economic treatment of the income effects of trade that predicts that trade openness benefits those owning factors of production with which their economy is relatively well endowed (those with skills in the advanced economies) while hurting others (low-skilled workers). We reexamine the available survey data, showing that the impact of education on attitudes toward trade is almost identical among respondents in the active labor force and those who are not (even those who are retired). We also find that, while individuals with college-level educations are far more likely to favor trade openness than others, other types of education have no significant effects on attitudes, and some actually reduce the support for trade, even though they clearly contribute to skill acquisition. Combined, these results strongly suggest that the effects of education on individual trade preferences are not primarily a product of distributional concerns linked to job skills. We suggest that exposure to economic ideas and information among college-educated individuals plays a key role in shaping attitudes toward trade and globalization. This is not to say that distributional issues are not important in shaping attitudes toward trade-just that they are not clearly manifest in the simple, broad association between education levels and support for free trade.
\end{abstract}

A growing body of scholarly research has examined survey data on attitudes toward trade among voters, focusing on individual determinants of protectionist sentiments. These studies have converged on one central finding: fears about the distributional effects of trade openness among less-educated, blue-collar workers lie at the heart of much of the backlash against globalization in the United States and other advanced economies. Support for new trade restrictions is highest among

The authors would like to thank James Alt, Jeffry Frieden, Robert Lawrence, Dani Rodrik, Ron Rogowski, Ken Scheve, Andy Baker, Peter Gourevitch, and Beth Simmons for helpful comments on earlier drafts.

International Organization 60, Spring 2006, pp. 469-498

DOI: $10.1017 / \mathrm{S} 0020818306060140$ 
respondents with the lowest levels of education. ${ }^{1}$ These findings are interpreted as strong support for the Stolper-Samuelson theorem, the classic economic treatment of the income effects of trade that predicts that trade openness benefits those owning factors of production with which their economy is relatively well endowed (those with high-skill levels in the advanced economies) while hurting others (lowskilled and unskilled workers).

However, the positive relationship between education and support for trade liberalization might also-and perhaps primarily - reflect the facts that more educated respondents tend to be more exposed to economic ideas about the overall efficiency gains for the national economy associated with greater trade openness and tend to be less prone to nationalist and antiforeigner sentiments often linked with protectionism. ${ }^{2}$ Studies have shown that measures of economic knowledge are strongly associated with education levels among individuals, and exposure to economics at the college level has especially powerful effects. ${ }^{3}$ A large body of research also shows that increased education - and especially college educationtends to socialize students to have more tolerant, cosmopolitan views of the world. ${ }^{4}$ It thus seems quite possible that differences of opinion among more and lesseducated voters over the trade issue may be shaped less by Stolper-Samuelson style calculations about the expected distributional effects of trade than by competing ideational and cultural perspectives-that is, education may be important here primarily because it teaches students to think about trade and globalization in different ways and/or to evaluate it according to a different set of values.

Which of these very different interpretations is more correct? The answer to this question is critical to our understanding of the political economy of trade and the nature of the political disagreements over globalization now taking place. Here we reexamine the available survey data on individual attitudes toward trade, conducting a simple test of the effects of education on support for trade that distinguishes clearly between the Stolper-Samuelson interpretation of this relationship and alternative ideational and cultural accounts. We find that the impact of education on attitudes toward trade is almost identical among respondents currently in the active labor force and among those who are not (even those who are retired). That the effects of education on trade policy preferences are not mediated by whether or not individuals are actually being paid for the employment of their skills strongly suggests that it is not primarily a product of distributional concerns. The analysis also reveals clear nonlinearities in the relationship between education and trade preferences: while individuals who have been exposed to college or university education are far more likely to favor trade openness than those who have not, other types of educational attainment have no significant effects on attitudes and some even reduce the likelihood that individuals support trade even

1. See, for example, Scheve and Slaughter 2001a and 2001b; Mayda and Rodrik 2005; and O'Rourke and Sinnott 2002.

2. See Bauer, Pool, and Dexter 1972, 103; and Holsti 1996, 87-88.

3. See Saunders 1980; and Gleason and van Scyoc 1995.

4. See for example, Campbell et al. 1960, 475-81; and Erikson, Luttbeg, and Tedin 1991, 155-56. 
though they clearly contribute to skill acquisition. These findings indicate that the particular ideational and/or cultural effects associated with college education, and not the gradual accumulation of skills, are critical in shaping individual attitudes toward trade.

We conclude that the impact of education on how voters' think about trade and globalization has more to do with exposure to economic ideas and information about the aggregate and varied effects of these economic phenomena, than it does with individual calculations about how trade affects personal income or job security. This is not to say that the latter types of calculations are not important in shaping individuals' views of trade-just that they are not being manifest in the simple association between education and support for trade openness. As we discuss in the concluding section, we think it is likely that concerns about the effects of trade on personal income and job security might actually hinge on the particular impact of trade openness in specific industries. One of the key implications of our findings is that future empirical tests of the determinants of individual trade preferences need to be substantially refined to identify the impact of distributional concerns on attitudes toward trade and globalization and distinguish these from the impact of ideational and cultural factors.

\section{Explaining Attitudes Toward International Trade}

To date, the analysis of survey data aimed at revealing the determinants of individual attitudes toward trade has focused predominantly on occupational differences among respondents. A principal aim has been to test standard economic models that describe the income effects of trade for different individuals as a function of the types of productive inputs they own. Examining data from recent American National Election Studies (NES) surveys in the United States, Scheve and Slaughter emphasized the importance of respondents" "human capital" or skills (measured principally by years of education), finding that individuals with lower skills were more likely to support restrictions on imports than those with higher skills. ${ }^{5}$ Mayda and Rodrik and O'Rourke and Sinnott came to similar conclusions after examining the data from the 1995 ISSP survey: again skill levels, measured either by years of education (Mayda and Rodrik) or occupational categories (O'Rourke and Sinnott), were found to have large effects on attitudes, with lower skilled individuals being the most protectionist in outlook. ${ }^{6}$ In terms of economic theory, these findings have been interpreted as providing strong support for the Stolper-Samuelson theorem, which predicts that trade raises real

5. Scheve and Slaughter 2001a and 2001b.

6. See Mayda and Rodrik 2005; and O'Rourke and Sinnott 2002. Similar types of findings are reported by Balistreri 1997; and Beaulieu 2002, who examined data on support for the Canadian-U.S. Free Trade Agreement in Canada; by Gabel 1998, who used Eurobarometer data on attitudes toward European integration; and by Baker 2003, using similar survey data on attitudes toward trade in Latin American nations. 
incomes for those who own factors with which the economy is relatively well endowed (that is, labor skills in the developed economies), while disadvantaging owners of other factors (unskilled or low-skilled labor). ${ }^{7}$ Scheve and Slaughter highlight as a "key finding" of their study the conclusion that "the preferences about trade and immigration policy align strongly with labor market skills." 8 Mayda and Rodrik report that the results from their analysis of the importance of educational attainment in shaping views about trade are "strikingly supportive of the implications of the factor-endowments model and of the Stolper-Samuelson theorem." 9

Yet there are other, plausible, ways to interpret the positive relationship between the education levels of surveyed individuals and their support for trade openness. It seems particularly limiting to consider education only as a measure of workers' skill levels, relevant only in the way it affects the expected income effects of trade for each individual. Education may be relevant here for other reasons-other causal mechanisms may be generating the observed association between education levels and protrade attitudes. We think there are two likely candidates: an ideational mechanism that hinges on the role played by economic ideas and knowledge in the formation of economic policy preferences; and a cultural mechanism that relates commitments to key values, such as tolerance and cosmopolitanism, to attitudes toward foreign policy issues.

The ideational argument is fairly straightforward. Highly educated respondents are likely to think about international trade in different ways compared to lesseducated counterparts; the highly educated use a more sophisticated set of ideas about cause-and-effect relationships and more information about the effects of trade for themselves and for others. ${ }^{10}$ College-educated individuals, in particular, are likely to be far more informed than others about the aggregate efficiency gains associated with expanded trade, especially if they have had any contact at all with economics courses and with the theory of comparative advantage. While there is a firm consensus among economists on the virtues of trade openness, the counterintuitive loveliness of the law of comparative advantage makes it much more difficult to convey the case for trade outside the college classroom. ${ }^{11}$ Studies of economic "literacy" among the public have shown that general measures of economic knowledge are strongly associated with education levels among individuals, and college education in particular. ${ }^{12}$ Exposure to at least one college-level economics course is an especially powerful predictor of economic knowledge. Crit-

7. Stolper and Samuelson 1941. This theorem has been used extensively in the analysis of trade politics; see Rogowski 1989; and Hiscox 2002.

8. Scheve and Slaughter 2001b, 9.

9. Mayda and Rodrik 2005, 1409.

10. Among scholars who have examined surveys of public attitudes toward trade, the topic is typically regarded as a complex issue about which most survey respondents have low levels of information; see Bauer, Pool, and Dexter 1972, 81-84; Destler 1995, 180; and Pryor 2002.

11. See Krugman 1993.

12. See, for example, Saunders 1980; and Gleason and van Scyoc 1995. 
ically, related studies show that higher levels of economic knowledge among surveyed individuals have large positive effects on support for free trade. ${ }^{13}$

This type of ideational argument does have precedents in both the international political economy and broader international relations literatures. Ideas, viewed as beliefs about cause-and-effect relationships, have been assigned key roles in accounts of policymaking in a variety of areas, including international cooperation on environmental issues and arms control. ${ }^{14}$ On the trade issue specifically, scholars have linked the removal of mercantilist restrictions on trade in Europe in the nineteenth century to the ideas of Smith and Ricardo and the birth of classical trade theory. ${ }^{15}$ The multilateral trade liberalization pursued among Western nations after 1945 has been connected to neoclassical economic theories and the spread of Keynesian ideas in particular. ${ }^{16}$ These types of accounts have traditionally focused on the importance of particular ideas among policymakers, and the transmission of ideas to government officials via transnational networks of experts and activists. ${ }^{17}$ Examining the distribution of economic ideas among voters, and how this might be connected to policy preferences, might be an interesting and important extension.

Another plausible explanation for the relationship between education and attitudes toward trade focuses on differences in cultural values: highly educated individuals are less prone than others to nationalist and antiforeigner sentiments that are often linked with protectionism in political debates. There is a large scholarly literature showing that education, at least in the United States, tends to socialize students to have more tolerant, pro-outsider views of the world. ${ }^{18}$ Education can foster tolerance, not just by increasing students' knowledge of foreign cultures and raising levels of critical thinking, but also by generating more diverse and cosmopolitan social networks, especially at the college level. ${ }^{19}$ Indeed, Betts has argued that one aspect of class identity that emerges among the college educated in Western nations is a commitment to cosmopolitanism and an appreciation for diverse cultures. ${ }^{20}$ Studies of survey data also show that various measures of nationalism and national pride are significant predictors of support for trade protection. ${ }^{21}$

13. See Walstad 1997; and Walstad and Rebeck 2002. Walstad and Rebeck 2002 make the larger point that scholarly analysis of public opinion on economic issues makes the erroneous implicit assumption that survey respondents are undifferentiated in terms of their economic knowledge. In fact, individuals differ dramatically in their levels of economic knowledge, as measured by their scores on a set of test questions covering basic economic concepts and facts, and such knowledge scores are significant predictors of attitudes about a range of economic policy issues.

14. For a general discussion, see Goldstein and Keohane 1993; on environmental negotiations, see Haas 1992; on arms control, see Adler 1992; and Price 1998.

15. See Kindleberger 1975; and Bhagwati 1988.

16. See Ruggie 1998; and Goldstein 1988. See also Hall 1989 for essays on the particular impact of Keynesian macroeconomic theory among policymakers in the 1930s and 1940s.

17. For example, Haas 1992; and Keck and Sikkink 1998.

18. For example, Campbell et al. 1960, 475-81; Erikson, Luttbeg, and Tedin 1991, 155-56; and McClosky and Brill 1983.

19. See Case, Greeley, and Fuchs 1989; and Allport 1954.

20. Betts 1988.

21. See Mayda and Rodrik 2005, 1414-16; and O'Rourke and Sinnott 2002, 173. On these points, see also Holsti 1996, 87-88. 
This type of argument resonates with a growing body of research in international relations that focuses on the importance of cultural values and conceptions of identity and how they shape the interests pursued by policymakers in international affairs - in areas including military strategy, humanitarian intervention, and support for human rights. ${ }^{22}$ It is more difficult to find cultural accounts of trade politics or policymaking, specifically, in the political economy literature, though references to the popular appeal of protectionism when linked with nationalism and xenophobia are common. ${ }^{23}$

How then should we interpret the observed connection between education and support for trade? Besides the standard account, which focuses on StolperSamuelson style distributional concerns, alternative accounts that stress the importance of economic ideas and related values also seem highly plausible. We suggest a simple test to establish whether the education connection is primarily reflecting concerns about the effects of trade on respondents' personal incomes, or whether it is a manifestation of broader differences in ideas and/or values among surveyed individuals. We examine the impact of education levels on attitudes toward trade among respondents currently in the active labor force and among those who are not. If the Stolper-Samuelson interpretation of the education effect is accurate, this effect should be contingent on whether or not individuals are actually being paid for the employment of their skills in the labor market. ${ }^{24}$

\section{The Effects of Education on Trade Preferences}

Our new empirical tests draw from two key sources of data on individual trade preferences: the NES and the International Social Survey Program (ISSP). These are the same data sets employed by the two most prominent studies of individual attitudes toward trade in recent years: the analyses by Scheve and Slaughter and Mayda and Rodrik. ${ }^{25}$ In the following section we briefly describe each dataset and present the results for our split-sample tests.

\section{Tests Using the NES Data}

The NES surveys are fielded in the United States around the time of presidential elections and designed to gather data on Americans' social backgrounds, political predispositions, opinions on questions of public policy, and participation in polit-

22. For general discussions, see Wendt 1999; Ruggie 1998; and Finnemore and Sikkink 1998. For studies of strategy, see Katzenstein 1996; on human rights, see Sikkink 1993.

23. For example, Bauer, Poole, and Dexter 1972, 103.

24. Similar split-sample tests have been used in studies of anti-immigrant sentiments to help discern whether greater opposition to immigration among less educated survey respondents (compared with more educated counterparts) reflects different degrees of concern about having to compete with immigrants in the job market: see Scheve and Slaughter 2001c; Mayda 2004; and also Hainmueller and Hiscox 2004.

25. Scheve and Slaughter 2001a, 2001b; and Mayda and Rodrik 2005. 
ical life. ${ }^{26}$ In 1992, for the first time, the NES included a question that asked respondents about their attitudes toward international trade. The question was the following: "Some people have suggested placing new limits on foreign imports in order to protect American jobs. Others say that such limits would raise consumer prices and hurt American exports. Do you favor or oppose placing new limits on imports, or haven't you thought much about this?"

Scheve and Slaughter used responses to this question from the 1992 NES survey as their measure of individual trade policy preferences. ${ }^{27}$ We have replicated their approach here to conduct the split-sample test, while also examining data from the 1996 NES survey that included the same trade question. ${ }^{28}$ We created the dichotomous dependent variable TRADE OPINION, coded as 1 for responses that favored protection ("new limits on foreign imports") and 0 for those opposed. The "haven't thought much about this" answers are coded as missing, as in the Scheve and Slaughter analysis.

The principal measure of education is SCHOOLING, which simply records the years of full-time education completed by each respondent (a cap is set by the NES at seventeen years). This is the measure employed by Scheve and Slaughter. To allow for nonlinear education effects, we have also constructed a set of dummy variables indicating each respondent's highest level of educational attainment: junior high $(1=8$ years of schooling; $0=$ otherwise $)$; high school $(1=$ high school degree; $0=$ otherwise $)$; higher education $(1=$ some years of post high school education, including junior or community college; $0=$ otherwise); college ( 1 = four-year bachelor's degree; $0=$ otherwise); and graduate $\left(1=\right.$ postgraduate degree; $0=$ otherwise).$^{29}$ Assuming that education has linear effects on trade preferences seems appropriate if one assumes that each additional year education (of any type) improves an individual's skills (and changes his or her attitudes) by a roughly constant amount. It is less appropriate if education has other, nonlinear types of effects associated with the ideas and information individuals possess about the way the economy works or the kinds of values and preferences they develop - as noted above, college education appears to play an overwhelming role in terms of its impact on ideas and cultural values among individuals.

For different subsamples of respondents, we estimated binary probit models using TRADE OPINION as the dependent variable, testing for the effects of SCHOOLING or the different education dummy variables while controlling for a variety of other individual characteristics that might plausibly affect trade preferences. We estimated each model with two sets of covariates: a limited set of standard sociode-

26. For details, see Miller et al. 1992; and Rosenstone 1996. For more on NES see 〈http://www. umich.edu/ nes/ $\rangle$. Accessed 10 January 2006.

27. Scheve and Slaughter 2001a.

28. Also examined in Scheve and Slaughter 2001b.

29. Note that there are too few respondents who failed to finish elementary school to allow us to estimate the separate effect of elementary level education here: the excluded category in our analysis of education effects when using these dummy variables is all those with less than eight years of schooling. 
mographic controls (age, in years, gender, and race), which preserved the maximum number of observations across the subsamples; and a more extensive set of controls (the standard controls plus indicators of UNION MEMBERSHIP, PARTY IDENTIFICATION, and IDEOLOGY), which closely matched the more extensive specifications used by Scheve and Slaughter. ${ }^{30}$ (See the Appendix for a description of all variables used along with summary statistics).

We expect the measures of education to be negatively associated with support for trade protection (as measured by TRADE OPINION), either because highly skilled individuals expect trade to increase their real wages and poorly skilled respondents expect trade to decrease their real wages (a la Stolper-Samuelson), because more educated respondents know more about the overall economic benefits associated with trade openness, and/or because the more educated are less likely to nurture antiforeigner sentiments. If this link between education and individual attitudes toward trade is primarily due to expectations about wages, however, the results from our estimations of trade preferences among respondents not actively engaged in the labor market should differ substantially when compared with those from our estimations of preferences among respondents who are currently employed. To test for this difference, we created subsamples of the full NES survey sample, separating those who were in paid work from those not in paid work. ${ }^{31}$ Since those not

30. We have used age in years, because this is the most straightforward approach and is the measure provided in the NES data; Scheve and Slaughter 2001b instead included a range of dummy variables covering separate age brackets. We have reestimated all our results using the respective age dummies and the results are virtually identical. We have also used dummy variables for multiple racial categories here, while Scheve and Slaughter appear to have used a single race dummy variable. Again, the results are almost identical regardless of how the race variable is entered in the models. The main variables we exclude are the ones constructed by Scheve and Slaughter using non-NES data: SECTOR NET EXPORT SHARE (net exports as a share of output for the industry in which the respondent is employed), and SECTOR TARIFF (customs duties as a share of the total value of imports for the industry in which the respondent is employed). Neither of these variables have significant effects on trade preferences, according to the results reported by Scheve and Slaughter (2001b, 59-60), and their inclusion in the estimations makes no difference at all to the estimated effects of education on trade opinion. We also excluded the other variables Scheve and Slaughter derive from non-NES data-the measure of OCCUPATION WAGE (the national average weekly wage for the respondent's occupation, which they use as an alternative to years of education as an indicator of skill level), and measures of COUNTY EXPOSURE to trade liberalization (the shares of total employment in the respondent's home county accounted for by industries with above average tariffs or net imports). Scheve and Slaughter find that county exposure, when interacted with a dichotomous indicator of home ownership, does have a significant negative impact on support for trade openness, but the inclusion of these added controls in their models has a minuscule and statistically insignificant effect on the estimated impact of education on trade preferences $(2001 \mathrm{a}, 285 ; 2001 \mathrm{~b}, 64)$, so we have not attempted to replicate the construction of these added controls here. Note that, because there is very little missing data for variables measured in the NES (the schooling measure has only 6 percent of observations missing in 1992, and 0 percent missing in 1996), and there is less missing data for all the other variables), we do not have to resort to imputation of missing data-Scheve and Slaughter (2001a, 278) report having to impute up to 73.4 percent of the observations for other (non-NES) variables they included in their analysis.

31. The subsamples are determined by answers to a NES question asking respondents about their current employment status. Answer choices included the following: working now, temporarily laid-off, unemployed, retired, student, homemaker, and permanently disabled. Our "currently in paid work" subsample includes those that answered "in work now"; those answering otherwise are classified as "currently not in paid work." Those with missing employment status are coded as missing. We also 
currently in paid work include a varied set of individuals, such as those that are unemployed, students, and homemakers (and may be seeking paid work or plan to seek to work soon), we have also isolated one particular group-those individuals who are retired-who are highly unlikely to reenter paid work in the future and be concerned about how their (potential) wages might be affected by trade. ${ }^{32}$

The key results from the estimations are reported in Table 1, which displays the estimated effects of education on individual trade preferences in the full NES sample and in each of the different subsamples. To facilitate comparison across subsamples, rather than showing estimated probit coefficients, we report estimated marginal effects: that is, the change in the probability of favoring protectionism associated with an infinitesimal change in SCHOOLING (for the specific dummy variables for levels of highest educational attainment, the discrete change in the probability is shown).

Comparing the results across the subsamples, we find little difference in the estimated effects of education on attitudes toward trade. In all cases, the estimated effects of SCHOOLING are similar, both in terms of magnitude and level of statistical significance, across all models (none of the coefficients is significantly different from the others across subsamples at conventional levels). This is true for estimations using both the 1992 and the 1996 NES data. For example, in the case of the 1996 survey, using the extensive set of covariates, a change from zero to seventeen years of SCHOOLING (while holding the other covariates at their respective sample means) is associated with an average decrease in the probability of favoring protection of about 0.59 (s.e. 0.05) for the full sample, 0.51 (s.e. 0.09) for those currently in paid work, 0.48 (s.e. 0.11) for those currently not in paid work, and 0.53 (s.e. 0.11) for those who are retired (Models 9 to 12, Panel B). ${ }^{33}$ The observed relationship between education and trade preferences becomes even more similar across subsamples once we replace the scHOOLING measure with the separate education dummies. For example, compared to individuals with less than junior-high level educations, completing a COLLEGE education decreases the probability of being in favor of protection by about 0.28 (s.e. 0.08 ) for the full

include those few retired/students/disabled/homemakers who also indicated that they are "currently working more than 20 hours per week" in our "currently in paid work" subsample. When the latter are excluded from the "currently in paid work" subsample, the magnitudes of the schooling effect become, if anything, more similar across the in- and out-of-paid-work subsamples than in the results we show here. Full results of these robustness tests are available on request.

32. While pensions for retired workers in some prominent U.S. industries (for example, steel) have been linked to the financial health of their former employers, this is the exception and not the rule. Recent studies of U.S. retirees indicate that less than 17 percent of retirement income in the median household comes from employer-provided pension plans (see Sass 2003, 6; and Social Security Administration 2002). The connection between employer-provided pensions and the financial health of the firm also is attenuated by the standards for funding and fiduciary conduct established by the Employee Retirement Income Security Act in 1974 (see Sass 1997). On this issue, we might also note that we get identical results when we perform the same tests comparing retirees with workers using the ISSP data (see below), drawn from a variety of countries with a variety of pension and retirement income systems.

33. Predicted effects here, and below, are calculated using the "Clarify" software developed by King, Tomz, and Wittenberg 2001. For each such calculation, all other covariates are set at the sample mean values. 


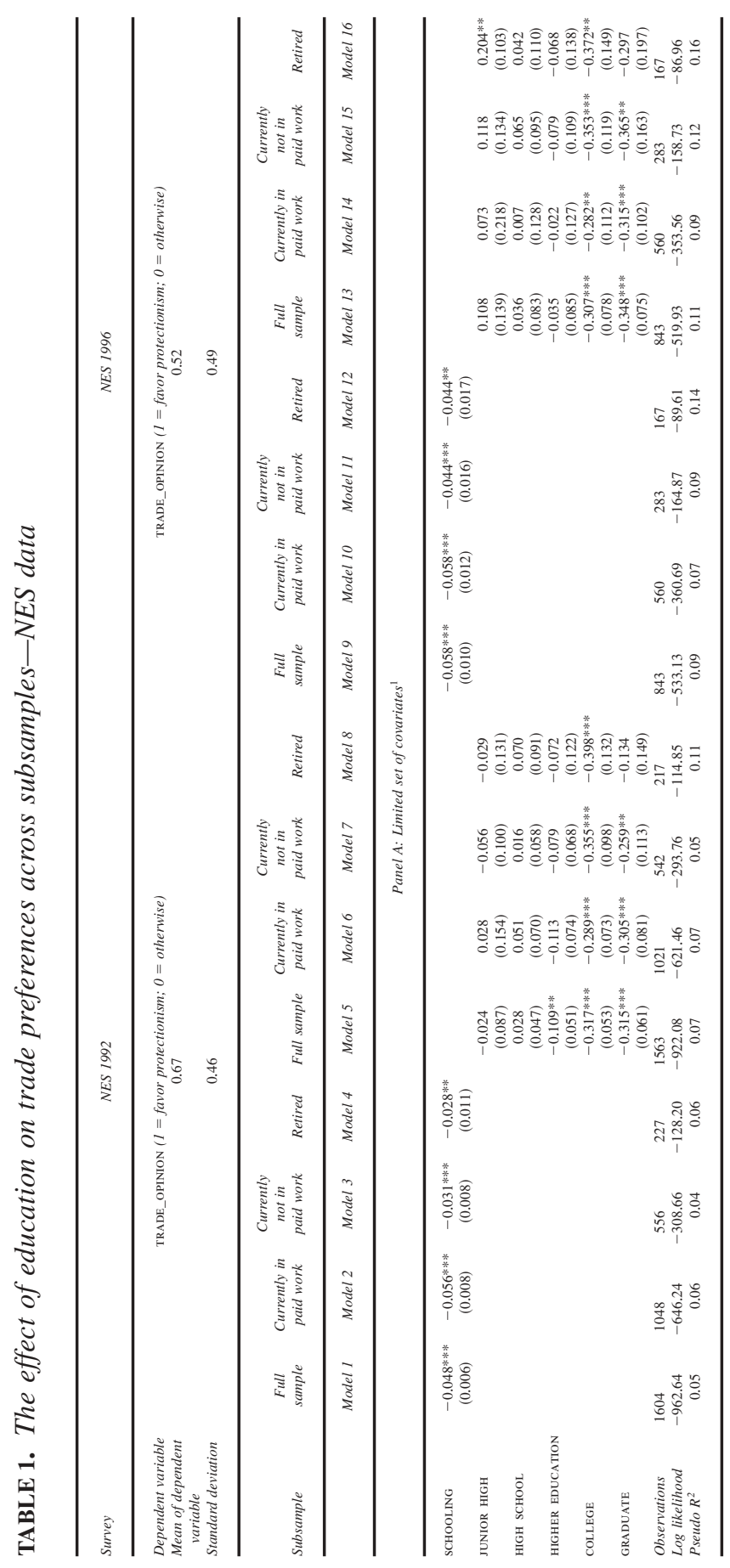


$\phi$

$\begin{array}{llll}\text { INO60(2) } 06014 & 11 / 30 & 02 / 22 / 06 & 3: 41 \\ \text { PM }\end{array}$

PAGE: 479

Education and International Trade $\mathbf{4 7 9}$

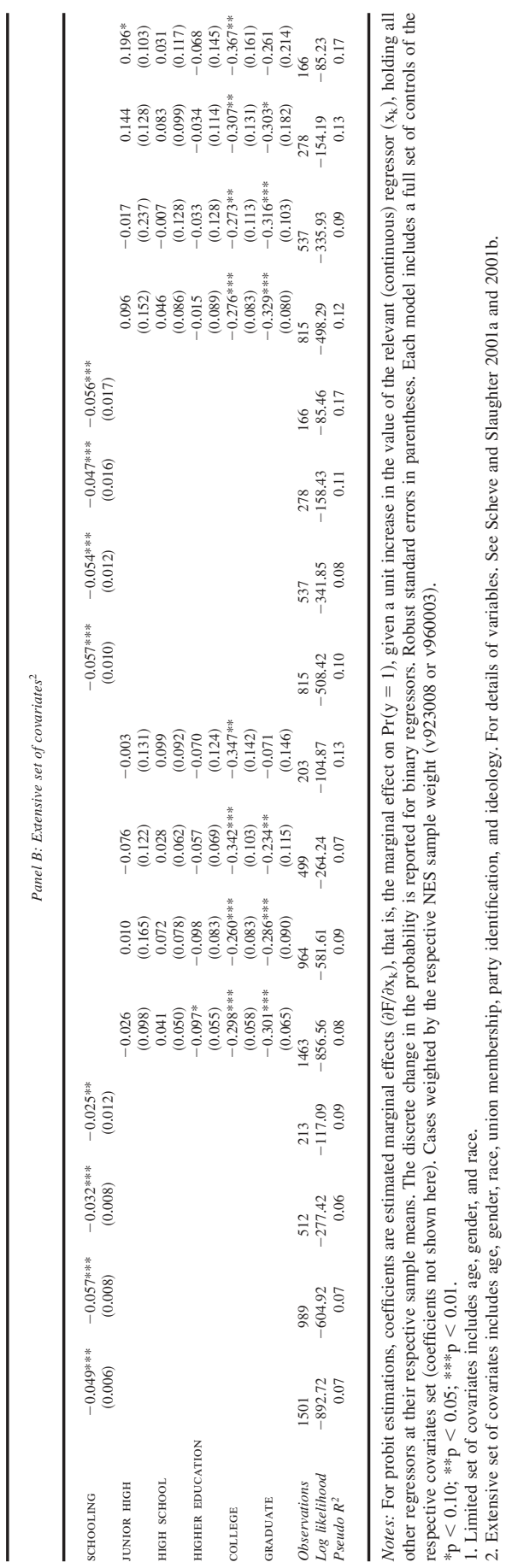

$\phi$

$\phi$ 
sample, by 0.27 (s.e. 0.11 ) for those currently in paid work, by 0.31 (s.e. 0.13 ) for those not in paid work, and by 0.37 (s.e. 0.16) for retirees (see Models 13 to 16, Panel B). ${ }^{34}$

Overall, these results clearly indicate that the link between education and trade preferences reflects a causal mechanism that is not associated with concerns about the labor market and relative wage rates. The findings here are consistent with both types of alternative interpretations, however, suggesting that more educated individuals favor free trade because they are more likely to understand the economic case for trade openness and/or because they possess more cosmopolitan (or less xenophobic) outlooks-because there is no reason to believe that the effects of education on the economic knowledge or cultural values possessed by different individuals is conditional at all on whether or not they are currently in the workforce.

These alternative interpretations are also supported by the clear nonlinearities that are apparent in the relationship between education and views about trade. Once we relax the linearity restriction imposed by simply counting years of education (the SCHOOLING measure), we can see that the effects of education on trade preferences are described by a nonlinear step function: college education has by far the greatest negative impact on support for protection, about three times larger than HIGHER EDUCATION (which is not itself a robust predictor), and about six times bigger than HIGH SCHOOL education (which is also not itself a robustly significant predictor and seems to have, if anything, a positive effect on support for protection) or completion of JUNIOR HIGH education (which also enters mostly insignificant and with alternate signs); the impact of GRADUATE education is almost identical to the effects of COLLEGE education. For instance, looking again at the estimates in the 1996 NES (full sample), and the limited set of covariates, compared with individuals with less than a JUNIOR HIGH education, completing COLLEGE education reduces the probability of supporting protection by 0.31 (s.e. 0.08), compared to only 0.04 (s.e. 0.09) for HIGHER EDUCATION; finishing HIGH SCHOOL education raises the probability of support for protection by 0.04 (s.e. 0.08) and so does completing JUNIOR HIGH grades by 0.11 (s.e. 0.14 ), though all three latter effects are not statistically significant. Meanwhile, completing GRADUATE education reduces the probability of protectionist views by 0.35 (s.e. 0.08 ), an effect not significantly different from that associated with completing an undergraduate college education (see Model 13, Panel A).

There appears to be a clear "plateau" effect here, with exposure to COLLEGE education being the critical contributor to the generally positive relationship between education and support for free trade. This college plateau effect seems out of place with the theory about labor market competition and its effects on trade preferences, especially because it applies to retirees as much as to those individuals currently active in the job market. On the other hand, this pattern fits much better with alternative approaches to explaining attitudes toward trade and the foreign

34. Note that since we show marginal effects, the magnitudes of the effects of the dichotomous education variables can be read directly from the table. 
affairs that focus on competing ideational and cultural perspectives and the way education-but especially college education-teaches students to think about trade and globalization in different ways or to evaluate it by different standards.

\section{Tests Using the ISSP Data}

Our second data set is the 1995 National Identity module of the ISSP, the main data examined by Mayda and Rodrik in their recent study of the determinants of individual trade preferences. ${ }^{35}$ The ISSP collects cross-national data by coordinating and combining national surveys on a variety of topics: the 1995 module posed a variety of questions about national identity, patriotism, attachments to local communities, feelings about foreigners, and attitudes toward foreign trade and immigration. ${ }^{36}$ It provides information on some 28,500 respondents from twenty-three countries, including the United States, Canada, Japan, many Western and Eastern European countries, and one developing country (the Philippines). ${ }^{37}$

Our treatment of the ISSP data follows precisely the measurement and estimation strategies employed by Mayda and Rodrik. Accordingly, we measure individual trade policy preferences using respondents' answers to the following question: ${ }^{38}$

Now we would like to ask a few questions about relations between (respondent's country) and other countries. How much do you agree or disagree with the following statements: (Respondent's country) should limit the import of foreign products in order to protect its national economy.

Options:

- Agree strongly

- Agree

- Neither agree nor disagree

- Disagree

- Disagree strongly

- Can't choose, don't know

- NA, refused

Following Mayda and Rodrik, we created two binary variables, labeled PROTRADE-DUMMY and AGAINST-TRADE-DUMMY, based on responses to this question. PRO-TRADE-DUMMY is coded 1 for individuals opposing trade protection (that is,

35. Mayda and Rodrik 2005.

36. For details, see ISSP 1995. See also 〈http://www.issp.org/〉.

37. The specific countries are West Germany, East Germany, Great Britain, United States, Austria, Hungary, Italy, Ireland, Netherlands, Norway, Sweden, Czech Republic, Slovenia, Poland, Bulgaria, Russia, New Zealand, Canada, Philippines, Japan, Spain, Latvia, and Slovak Republic.

38. See Mayda and Rodrik 2005, 1401, for a discussion of the potential problems associated with the question wording. 
for those replying "disagree" or "disagree strongly" to the question), and 0 otherwise. AGAINST-TRADE-DUMMY is coded 1 for individuals favoring trade protection (that is, for those replying "agree" or "agree strongly" to the question), and 0 otherwise. Accordingly, the "Can't choose, don't know" and "NA, refused" responses are coded as zero. Since the results from the estimations of the PROTRADE-DUMMY and AGAINST-TRADE-DUMMY are substantively similar, we just emulate Mayda and Rodrik here and present only the results using the analysis of the PRO-TRADE-DUMMY. ${ }^{39}$

Once again the principal measure of education, SCHOOLING is simply a count of the years of full-time education completed by each respondent (we follow Mayda and Rodrik and set a cap at twenty years). In order to test for nonlinearities in the effects of education on attitudes, we again construct a set of highest educational attainment dummy variables that include SECONDARY INCOMPLETE $(1=$ some secondary education; $0=$ otherwise $)$, HIGH SCHOOL $(1=$ high school degree; $0=$ otherwise), and COLlege ( $1=$ university education; $0=$ otherwise $)$. The reference category here comprises those respondents who have only a primary school education (or less). Unlike the NES data, the ISSP does not allow us to distinguish any finer categories here; no separate coding for graduate education is available, so the college category here includes respondents with advanced or higher university degrees (and those who attended college but did not complete a degree).

Our estimation strategy is identical to that one we applied for the analysis of the NES data. We estimate two series of binary probit models in which the PROTRADE-DUMMY is estimated using either SCHOOLING or the set of education dummy variables and other covariates. We estimated all the models for all subsamples using three sets of controls. Our limited set of controls includes just age, gender, and citizenship and a full set of country dummies. This mirrors precisely the baseline specification as presented in the analysis by Mayda and Rodrik. ${ }^{40}$ Our extensive set of controls matches those included in their "demographic model" and includes age, gender, citizenship, area of residence (that is, rural, suburban, or urban residence), subjective social class, party affiliation, trade union membership, the log of real income and a full set of country dummies. ${ }^{41}$ Our third model mirrors Mayda and Rodrik's "factor endowments model." It includes the covariates AGE, MALE, CITIZEN, and a full set of country dummies, as well as a SCHOOLING*GDP multiplicative term that interacts the schooling measure with the $\log$ of gross domestic product (GDP) per capita in the respondent's country along-

39. Mayda and Rodrik note that their results are also unchanged if they treated "Can't choose, don't know" and "NA, refused" as missing data, and the same is true for our findings. In addition, Mayda and Rodrik report that they also used a categorical dependent variable (labeled TRADE_OP) to estimate ordered logit (and OLS regression) models and obtained "very similar" substantive results $(2005,1397)$.

40. Mayda and Rodrik 2005, 1403, tab. 4, col. 1.

41. Following Mayda and Rodrik 2005, we compute real income using data in local currency from the ISSP dataset and purchasing power parity conversion factors taken from the World Bank's World Development Indicators database. See 〈http://www.worldbank.org/data/wdi2004/〉. Accessed 10 January 2006. 
side the main effect of schooling. ${ }^{42}$ The goal is to capture potential cross-country heterogeneity with respect to the education effect. GDP per capita is used as a simple indicator of relative factor abundance; the assumption is that higher levels of GDP per capita are associated with a greater abundance of skilled labor. According to the Stolper-Samuelson theorem, skilled individuals will gain in terms of real wages and thus should be likely to favor trade openness, in countries that are abundantly endowed with skilled labor, but the size of those gains should be proportional to the degree of skill abundance in each country (and, of course, in countries that are actually poorly endowed with skilled labor relative to potential trading partners, those gains may become losses). In terms of the anticipated results this means that the SCHOOLING*GDP interaction term should be positive. In every model we calculate robust standard errors allowing for potential within-country clustering. (See the Appendix for descriptions of all variables and summary statistics).

Again we created subsamples of the full ISSP survey sample, separating those who were "in paid" work from those "not in paid" work. Since the ISSP variable coding the employment status of respondents also differentiates between those in full- and part-time employment, we define those in (and not in) paid work using both possible combinations (just those in full-time work or all those working) ${ }^{43}$ Again, we have estimated the models separately for those individuals who are retired. We estimated all models for the full sample first, and then for each particular subsample. The results are reported in Table 2, which displays just the estimated marginal effects of education on trade preferences.

Overall, the findings from the analysis of the ISSP data are similar to the results from the analysis of the NES data reported above. Here the estimated effects of SCHOOLING on attitudes toward trade are almost identical, both in terms of magnitude and level of statistical significance, across all subsamples, and regardless of whether we examine the baseline (Panel A), the demographic (Panel B), or the factor endowment models (Panel C). None of the schooling effects are significantly different from others across the subsamples at conventional levels. For example, in the baseline model, a shift from zero to twenty years of schooling (while holding the other covariates at their respective sample means) increases the probability of favoring trade by about 0.34 (s.e. 0.05 ) in the full sample, by 0.37 (s.e.

42. GDP per capita data is taken from the World Bank's World Development Indicators (1995 current international dollars, adjusted for purchasing power parity). Note that the direct effect of country GDP per capita on the attitudes of respondents is captured by the country dummies and is not estimated separately. See Mayda and Rodrik 2005, 1405, for a detailed discussion of the specification.

43. The subsamples are determined by answers to a question asking respondents about their current employment status. Answer choices included the following: full-time employed, part-time employed, less than part-time employed, helping family member, unemployed, student, homemaker, retired, permanently disabled, and other. Our "currently not in paid work" subsample includes all those (not) answering "employed (either part-time or full-time)" to this question. Those with missing employment status are coded as missing. We also reestimated all models including those working "less than parttime" in the "currently in paid work" subsamples. The results are substantively identical to those in Table 2 (and are available on request). 
$\varnothing$

INO60(2) $06014 \quad 16 / 30 \quad 02 / 22 / 06 \quad 3: 41$ PM

PAGE: 484

484 International Organization

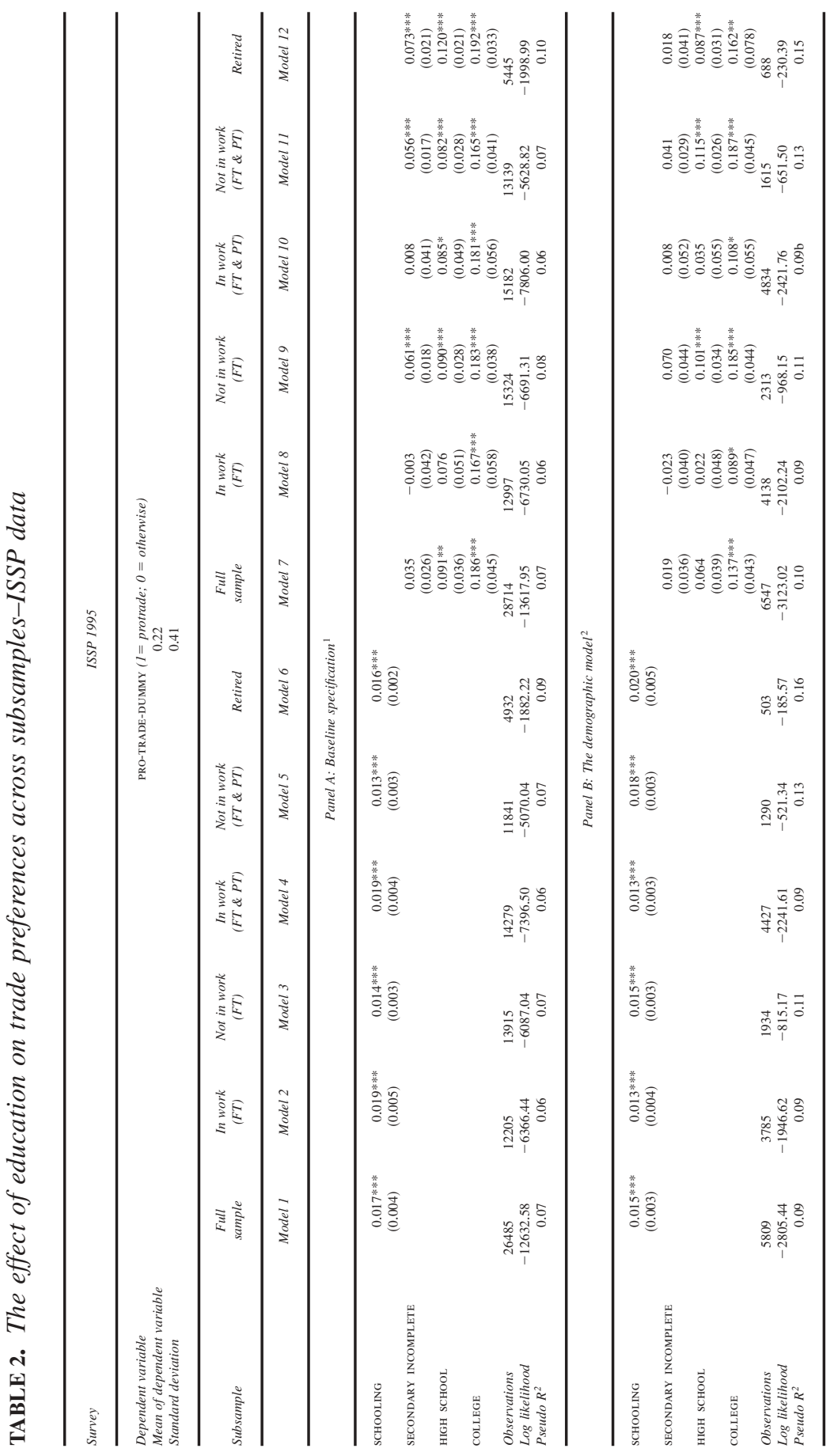


Education and International Trade $\mathbf{4 8 5}$

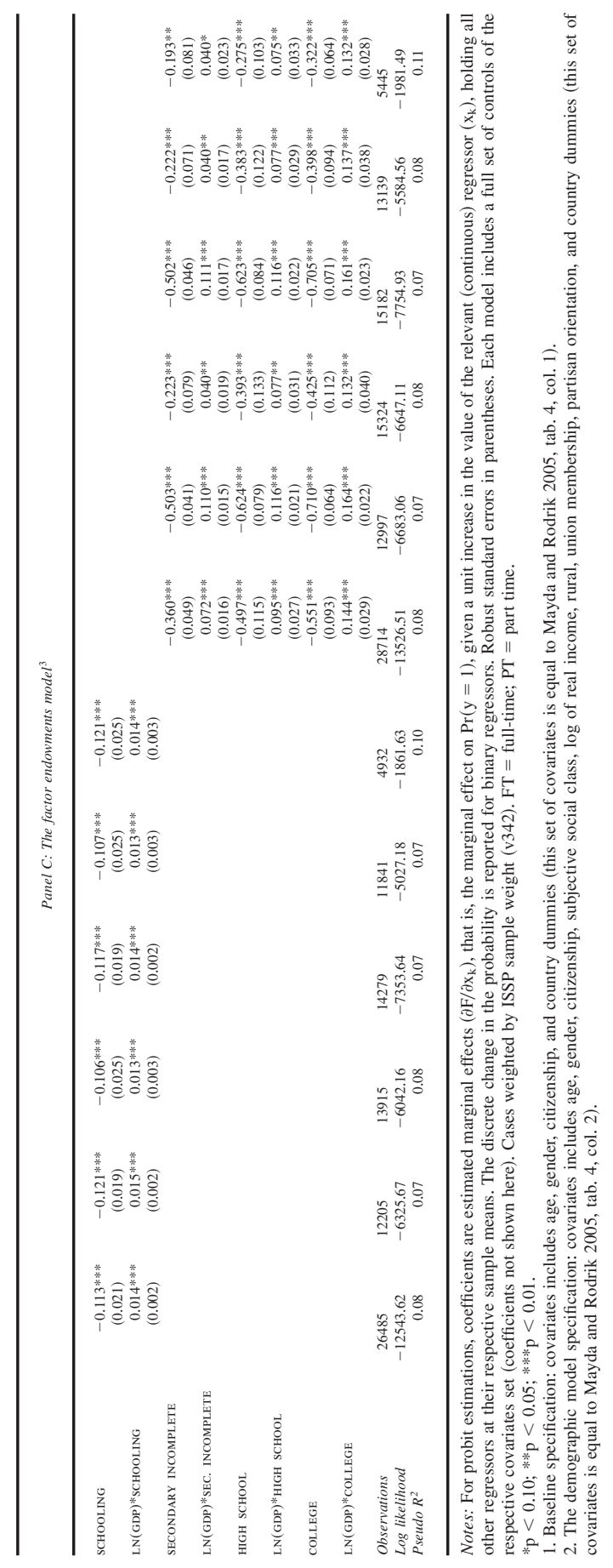


0.06) in the in (full-time) work subsample, by 0.31 (s.e. 0.05) for the not-in-fulltime-work subsample, and by 0.33 (s.e. 0.05) in the retired subsample (Models 1 to 6, Panel A). These estimated effects of education are very similar regardless of whether those working on a part-time basis are included in the "paid work" subsample or not. The same holds true if we account for potential cross-country heterogeneity with respect to the education effect (Panel C). Both the direct effect of schooling and its interaction with GDP per capita are almost identical across subsamples. The similarity in these effects across the different subsamples of respondents is again clearly at odds with the claim that the SCHOOLING coefficients are primarily indicative of concerns among respondents about the effects of trade openness on labor markets and relative wages.

If we relax the linearity restriction and replace the SCHOOLING measure with the education dummy variables, it is clear that the impact of the education on trade preferences remains very similar across the subsamples. It also becomes apparent again that the effects of education on opinions about trade are nonlinear. Specifically, COLLEGE education has by far the greatest positive effect on individual-level support for free trade, two-to-three times bigger than the impact of HIGH SCHOOL education (which is not a robustly significant predictor of attitudes); meanwhile, INCOMPLETE SECONDARY education appears to have little if any effect on support for free trade (only very few of the coefficients enter significant at conventional levels and some even switch signs). For instance, in the demographic model (Model 7, Panel B), and comparing with individuals with only primary level education, COLLEGE education shifts the probability of being protrade by 0.14 (s.e. 0.04) as compared to only 0.06 (s.e. 0.04) for completing HIGH SCHOOL education; and INCOMPLETE SECONDARY education increases the probability of being pro-free trade by a mere 0.02 (s.e. 0.04) - the latter two effects are insignificant at conventional levels. The same nonlinearities are clear when cross-country heterogeneity in the education effect is taken into account. For example, for the full sample in the factor endowments model (Model 7, Panel C), evaluated at the sample mean level of GDP per capita among the ISSP nations $(\$ 15,987)$, a COLLEGE education raises the probability of being protrade by 0.18 (s.e. 0.01 ) compared to a primary level education; the corresponding effect is only 0.09 (s.e. 0.01) for completing HIGH SCHOOL education, and an INCOMPLETE SECONDARY education increases the probability of being pro-free trade by a mere 0.04 (s.e. 0.01). The pattern here strongly resembles the college "plateau" effect found in the analysis of the NES data, and again confirms - this time based on data drawn from surveyed twenty-three nations - that exposure to COLLEGE education among individuals lies at the heart of the observable relationship between education and support for free trade. Regardless of which model we estimate, the college effect is strikingly similar across all subsamples.

One issue we need to address here concerns the cross-country heterogeneity with respect to the education effect that is evident in the results from the estimations of factor endowments model. As reported by Mayda and Rodrik, we find that the SCHOOLING*GDP interaction term is positive-in all of the subsamples. The implication is that the impact of education on individual attitudes toward trade 
varies by country depending on levels of economic development. For example, examining the full-sample estimates (Model 1, Panel C), a shift from zero to twenty years of ScHOOLING (other covariates at their respective sample means) increases the probability of favoring trade openness by about 0.49 (s.e. 0.03 ) in a country with GDP per capita of $\$ 22,039$ (that is, Germany in 1995) but by only 0.27 (s.e. 0.02) in a country with GDP per capita of $\$ 11,720$ (the Czech Republic in 1995).

This result is consistent with the Stolper-Samuelson theorem, but it also seems consistent with the alternative ideational and cultural accounts of the causal effects of education on attitudes toward trade (accounts that can also explain the similarity in the effects of education across labor-market subsamples in each country). In line with an ideational approach, it seems highly likely that there are important cross-national differences in the content and quality of instruction in economics at the college level that are related to cross-national differences in levels of development across these surveyed countries. Economists and other scholars in lessdeveloped countries may be more concerned than their counterparts in wealthier nations about the adjustment costs associated with trade liberalization, or the fairness of trade negotiations and agreements, and convey these concerns to students. Or, more in line with a cultural account that stresses the link between education and values, it also seems plausible that education systems in richer ISSP nations, which have longer histories of democratic institutions than poorer nations, may place greater emphasis on inculcating tolerance among students, and thus may more effectively discourage antiforeigner (and protectionist) sentiments. The general point here is that there are plausible explanations for the observed differences between richer and poorer ISSP countries in the effects of education on attitudes toward trade that fit with the ideational and cultural accounts; the similarities in the effects of education across subsamples of individuals within each country, and the college plateau effect, are also consistent with these same accounts, but they contradict the Stolper-Samuelson view. ${ }^{44}$

\section{Family Income Effects?}

It seems impossible to square the findings we have reported above with a simple Stolper-Samuelson reading of the effects of education on trade policy preferences. One possible counterargument, in defense of the Stolper-Samuelson interpretation, is that individuals who themselves are not employed or seeking employment are nevertheless concerned about the distributional effects of trade because it will have an impact on their total family or household income. Thus individuals who

\footnotetext{
44. In general we do not place great importance on the finding that the SCHOOLING*GDP interaction term is positive for the ISSP set of countries - in our analysis of the alternative Pew data on individual trade preferences, which includes a much larger and more varied set of countries (see discussion below), we do not find the same, simple positive relationship between GDP per capita and the magnitude of the education effect. The breakdown of this relationship among countries with more varied political and institutional histories suggests that it does not provide firm support for a Stolper-Samuelson interpretation. These results are available at $\langle$ http://www.people.fas.harvard.edu/ jhainm/Hainmueller Hiscox_IOa.html $>$.
} 
are not employed and describe themselves as "homemakers" may actually be making calculations about the effects of trade on the earnings of their spouse or partner when responding to survey questions. Similarly, retired individuals may be taking into account the effects of trade on the earnings of their children. If these are powerful concerns, and if there is a strong and positive within-family correlation in levels of education, expectations about within-family income transfers might feasibly explain the results we are reporting here in a way that would still be broadly consistent with the spirit of the Stolper-Samuelson theorem. To the best of our knowledge, this family income extension of the theorem has not actually been advanced or tested before-no such claims are made by Scheve and Slaughter or Mayda and Rodrik. On the face of it, we think this potential explanation seems quite implausible, given the clear similarities between the education effects across subsamples, the imperfect correlation between individual education attainment and spouses' or partners' (or children's) education levels, and the uncertainty attached to within-family income transfers. The connection between retirees' incomes and the earnings of their children seems especially tenuous, because most retirees in Western countries rely overwhelmingly on personal savings, retirement accounts, and state-provided pensions for their retirement income.

We tested the alternative explanation using the NES data, which provide the best available data on individual marital status. ${ }^{45}$ The NES includes the following question: "Are you married now and living with your (husband/wife)—or are you widowed, divorced, separated, or have you never married?" Following the NES recommendations, we created a dummy variable PARTNER, coded 1 if the respondent indicated he or she is currently living with a spouse or partner and 0 otherwise. To provide an explicit test of spouse and partner effects, we simply repeated all our split-sample analysis using the PARTNER variable to further divide each labor market subsample according to marital status. ${ }^{46}$ Dividing the sample in one more dimension results in a limited number of observations within each subsample, of course, so we estimate the model with only the limited set of covariates (including age, gender, and race) here, and we use only the 1992 NES data (the 1996 NES data contains half the total number of observations of the 1992 NES sample, as noted above) ${ }^{47}$ Results from these estimations are reported in Table 3. Again we report estimated marginal effects for the education variables so that magnitudes are directly comparable across subsamples.

45. Unfortunately, we cannot conduct a similar analysis for the ISSP survey, because far too much data is missing on the marital status of the respondents. We have repeated these tests using the data from the GAP survey, however, and have found substantively identical results (findings from these additional tests are also available from the authors).

46. We have also rerun our models for each subsample using a multiplicative term (PARTNER* SCHOOLING) alongside the main effect of PARTNER and the results are very similar to the ones reported below. Nonetheless, given the high correlation between the multiplicative and its lower-order terms we prefer the split-sample tests as our identification strategy.

47. Note too, that in the specifications that replace the single schooling variable with separate educational dummies, we also exclude the JUNIOR HIGH attainment dummy, because there are no observations for this category in some subsamples. 
Education and International Trade $\mathbf{4 8 9}$

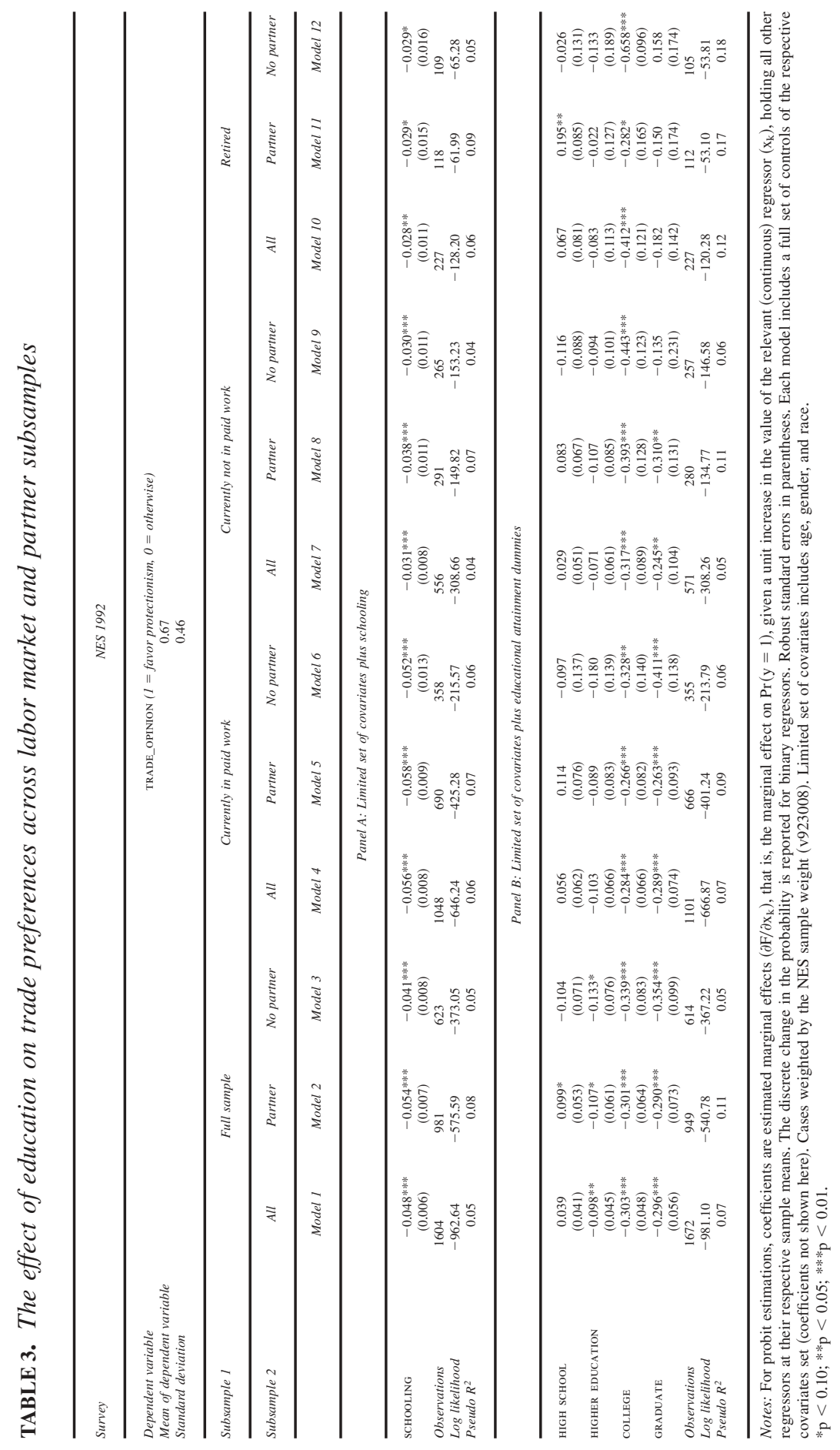


The similarities in the effects of education across subsamples appear again here, regardless of whether we limit the analysis to those respondents who have a spouse/partner or to those who do not. In all cases the estimated effects of SCHOOLING are similar, both in terms of magnitude and level of statistical significance. Most importantly, within and across each subsample, we cannot reject the null hypothesis that the education effects are identical (at the 90 percent level). For example, for the full sample estimates, a change from zero to seventeen years of SCHOOLING (while holding the other covariates at their respective sample means) is associated with an average decrease in the probability of favoring protection of about 0.48 (s.e. 0.03) for all respondents, 0.50 (s.e. 0.04) for those respondents that have a partner/spouse, and 0.44 (s.e. 0.06) for those that do not have a partner/spouse. Looking only at those that are currently in paid work, the respective decrease is 0.50 (s.e. 0.04) for all respondents, 0.51 (s.e. 0.05) for those that have a partner/spouse, and 0.47 (s.e. 0.08) for those that do not. For those respondents that are out of the workforce, the respective decrease is 0.35 (s.e. 0.07) for all, 0.38 (s.e. 0.09) for with a partner, and 0.35 (s.e. 0.11) for those without. Finally, for the retired subsample, the respective decrease is again very similar, about 0.32 (s.e. 0.11) for all, 0.33 (s.e. 0.14) for those with and 0.33 (s.e. 0.18) for those without a partner/spouse.

The same results emerge when we rerun the models, replacing the SCHOOLING measure with the EDUCATIONAL ATTAINMENT dummies. Most importantly, the key COLLEGE effect remains strikingly stable across models even if we divide the subsamples using the PARTNER variable. For example for the full sample, completing college education decreases in the probability of favoring protection by about 0.30 (s.e. 0.05) for all respondents, by about 0.30 (s.e. 0.06) for those with partner/ spouse, and by 0.34 (s.e. 0.08 ) for those without (all compared to those that did not complete a high school degree). For those currently in work, the respective decrease is 0.29 (s.e. 0.07) for all respondents, 0.27 (s.e. 0.08) for those with, and 0.33 (s.e. 0.14) for those without a partner/spouse. For those not working, the respective decrease is 0.32 (s.e. 0.09) for all respondents, 0.39 (s.e. 0.13) for those with, and 0.44 (s.e. 0.12) for those without a partner/spouse. The retired subsample reveals the greatest differences in magnitudes of the COLLEGE effect. The decrease in proprotection attitudes associated with completing COLLEGE is 0.41 (s.e. 0.12) for all respondents, 0.28 (s.e. 0.17) for those with, and 0.66 (s.e. 0.10) without a partner. This difference is, if anything, the opposite of what one would expect if one simply assumed that retirees with partners were assessing the effects of trade on the incomes of their (working and similarly educated) partners while retirees without partners were not.

If we just compare the effects of COLLEGE (or SCHOOLING) across subsamples of respondents that do not have partners-a test that presumably excludes the bulk of any family income effects-it is clear that these effects are not significantly different, regardless of whether those respondents are working, not working, or retired. Certainly the effects are not significantly larger for those being paid for the employment of their skills than for others, as implied by a simple StolperSamuelson interpretation of the impact of education. Overall, the findings suggest 
that a broader family or household interpretation of the Stolper-Samuelson theorem cannot account for the results we have found.

\section{Findings and Implications}

Previous research has concluded that the simple association that is evident between education and support for trade openness among survey respondents in the United States and other Western nations is proof positive of the Stolper-Samuelson theorem. That is, this relationship is seen as a straightforward confirmation that highskilled individuals in skill-abundant economies perceive that trade openness raises their real wages while low-skilled individuals calculate that their real wages decrease with trade liberalization. But if these calculations are paramount, the effects of education on individual trade policy preferences should be conditional on whether or not individuals are actually being paid for the employment of their skills in the labor market. Reexamining the available survey data on individual attitudes toward international trade in a variety of nations, we find that this is simply not the case. The impact of education on attitudes toward trade is almost identical among respondents currently in the active labor force and among those who are not-and even among those who are retired from work. In addition, the impact of education on attitudes is overwhelmingly attributable to college education. We have replicated all the tests we report above using two alternative cross-national survey data setsthe third wave of the World Values Survey carried out in 1995-97, and the Global Attitudes Project survey administered by Pew in 2003-and we have found substantively identical results. ${ }^{48}$

Given these results, a fundamental reinterpretation of the survey evidence on attitudes toward trade and globalization appears to be in order. The results reported above indicate that the effects of education levels on trade policy preferences are not primarily a reflection of distributional concerns among survey respondents. We suggest instead that the impact of education on how individuals think about trade and globalization has more to do with ideas and information about the aggregate effects of these economic phenomena. Some part of the effect of education on attitudes toward trade might also reflect the fact that college-educated individuals are less likely than others to harbor antiforeigner sentiments. Which of these two causal mechanisms - ideational or cultural—is more important? Unfortunately, no opinion surveys (of which we are aware) gather all the data that one would need to answer this question definitively. That is, no surveys ask respondents about their views regarding trade, also ask questions designed to measure economic knowledge or exposure to economic ideas, and also ask questions that would gauge individuals' commitments to values such as tolerance and cosmopolitanism. For now we only have some clues provided by studies of partial sets of data-but these clues suggest to us that the smart betting would be on the ideational argument.

48. Full results from all these separate tests are available in a supplement to this paper that can be downloaded at $\langle$ http://www.people.fas.harvard.edu/ jhainm/HainmuellerHiscox_IOa.html $\rangle$. 
One major clue comes from the available data on economic knowledge among the public and its impact upon trade policy preferences. As far as we are aware, the only survey that has actually combined measures of both economic knowledge and attitudes toward trade is the 1992 poll conducted by William Walstad and Max Larsen for the National Center for Research on Economics Education and for Gallup. ${ }^{49}$ To gauge "economic literacy"- - the main purpose of the study-the survey asked respondents a battery of substantive economic knowledge questions. What is especially interesting, in light of the discussion above, is that once this measure of specialized economic knowledge is included in estimations of individual support for trade openness, the effects of the standard measures of education on attitudes toward trade shrink dramatically in magnitude and none of these effects remains statistically significant. ${ }^{50}$ That is, economic literacy appears to account for most of the "raw" impact of education on attitudes about trade. ${ }^{51}$ This literacy effect is stable across various subsamples of respondents who are in the active labor force and those who are not.

On the other side of this coin, adding various measures of individuals' commitments to various relevant cultural values (such as tolerance and cosmopolitanism) to estimations of attitudes toward trade appears to have almost no effect at all on the magnitude or significance of the effects of standard measures of education. For instance, using the ISSP survey data that asked a large number of "identity" questions, Mayda and Rodrik introduced an array of controls for (self-expressed) national pride and attachment to local their communities when estimating individual support for trade protection. Many of these cultural variables had significant and sizeable effects on trade preferences, but they had no significant effect at all on the estimated effects of education on such preferences. ${ }^{52}$ Using a variety of different measures of racial and cultural tolerance available in the 1992 NES survey, we have found similar results - that is, while the various measures of tolerance among the respondents are themselves significant predictors of views about trade, they account for none of the raw impact of education on trade policy preferences. ${ }^{53}$

\section{Conclusions}

Finally, it is important to note that while these results indicate that the impact of education on trade preferences has more to do with ideas and economic literacy than it does with calculations about how trade affects personal income or job security, this is not to say that the latter types of calculations are not important in shaping individuals views of trade. Our conclusion in this article is just that the

49. See Walstad 1997; and Walstad and Rebeck 2002.

50. See Walstad 1997, 201.

51. Full results from our tests using the Walstad and Larsen data are available at $\langle$ http://www. people.fas.harvard.edu/ jhainm/HainmuellerHiscox_IOa.html $\rangle$.

52. Mayda and Rodrik 2005, 1414-16.

53. Results from all these separate tests are available from the authors are available at $\langle$ http://www. people.fas.harvard.edu/ jhainm/HainmuellerHiscox_IOa.html $\rangle$. 
simple association between education and support for free trade among surveyed individuals is not a clear manifestation of such distributional concerns. We strongly suspect that concerns about the effects of trade on personal economic well-being do play a large role in shaping trade policy preferences, but they are related much more directly to the impact that trade openness is expected to have in particular industries and firms. "Specific factors" models of the distributional effects of trade that, unlike the Stolper-Samuelson theorem, allow that factors of production are not perfectly mobile between different sectors in the economy, predict that the real incomes of individuals are tied closely to the fortunes of the particular industries in which they are employed or invested. ${ }^{54}$

To date, studies of individual trade preferences have indicated only weak (Mayda and Rodrik) or no (Scheve and Slaughter) support for the prediction that individuals employed in import-competing industries will be much less likely to support trade openness than those employed in exporting industries. But these studies have measured the industry-specific effects of trade in an indirect way, locating respondents by industry using answers to a standard question about the type of business in which they are employed, then controlling for the aggregate trade positions of those industries (for example, their degrees of import penetration) when estimating individual trade preferences. ${ }^{55}$ There are at least two major problems with this approach. First, accurately coding respondents by industry of employment using standard industrial classifications is extremely difficult, as respondents typically give vague answers to questions about the type of business in which they work. ${ }^{56}$ Second, aggregate industry measures of import penetration and export dependence may offer more information about policy outcomes than policy preferences, and they obscure the obvious variation in positions taken by firms in the subcategories within each broad industry grouping. ${ }^{57}$

One of the implications of our findings is that future survey-based measurements need to be substantially refined to better account for industry-specific effects if we are to accurately gauge the impact of distributional concerns on attitudes toward trade and globalization. ${ }^{58}$ Resolving these issues is crucial for improving-

54. See Jones 1971; and Mussa 1974. The specific factors approach underpins much of the most recent analysis of the political economy of trade in contemporary advanced economies: see Magee 1980; Grossman and Helpman 1994; and Hiscox 2002.

55. Scheve and Slaughter 2001a and $2001 \mathrm{~b}$ examine industry effects using this approach and industry coding supplied in the NES. Mayda and Rodrik 2005 were forced to take an extra step: because the ISSP data does not provide coding by industry, they inferred industry of employment from occupational codes assigned to respondents instead.

56. When the staff at the Panel Study of Income Dynamics checked a random sample of surveys, for instance, they found that industry codes differed across coders in 14 percent of cases. See Panel Study of Income Dynamics 1999.

57. The standard concern about using import penetration as a measure of an industry's trade policy preference is that low levels of penetration may reflect the effectiveness of a protectionist lobby (not the absence of concerns about import competition).

58. One recent study, for instance, questioned respondents directly about the likely impact of trade on the security of their particular job, asking them whether they felt that increasing trade made their job more secure, less secure, or had no clear effect (see Hiscox 2004). The estimated probability of support for trade was some 45 percent higher among respondents for whom trade had raised job security compared with those reporting that trade made their job less secure. 
494 International Organization

our understanding of the determinants of antiglobalization sentiments and the range of policies that might address them.

\section{Appendix: Summary Statistics and Variable Descriptions}

TABLE A1. Summary statistics for NES data

\begin{tabular}{|c|c|c|c|c|c|}
\hline \multirow[b]{2}{*}{ Variables } & \multicolumn{5}{|c|}{ NES 1992} \\
\hline & Observations & Mean & $\begin{array}{l}\text { Standard } \\
\text { deviation }\end{array}$ & Minimum & Махітит \\
\hline TRADE_OPINION & 1736 & 0.674 & 0.464 & 0 & 1 \\
\hline SCHOOLING & 2329 & 12.978 & 2.733 & 0 & 17 \\
\hline GRADUATE & 2420 & 0.076 & 0.264 & 0 & 1 \\
\hline COLLEGE & 2420 & 0.163 & 0.369 & 0 & 1 \\
\hline HIGHER EDUCATION & 2420 & 0.242 & 0.428 & 0 & 1 \\
\hline HIGH SCHOOL & 2420 & 0.343 & 0.475 & 0 & 1 \\
\hline JUNIOR HIGH & 2329 & 0.036 & 0.187 & 0 & 1 \\
\hline AGE & 2485 & 44.271 & 17.210 & 17 & 91 \\
\hline MALE & 2485 & 0.477 & 0.500 & 0 & 1 \\
\hline WHITE & 2450 & 0.845 & 0.362 & 0 & 1 \\
\hline BLACK & 2450 & 0.130 & 0.336 & 0 & 1 \\
\hline INDIAN & 2450 & 0.012 & 0.110 & 0 & 1 \\
\hline ASIAN & 2450 & 0.013 & 0.114 & 0 & 1 \\
\hline TRADE UNION MEMBER & 2472 & 0.108 & 0.310 & 0 & 1 \\
\hline PARTY ID & 2445 & 2.727 & 2.022 & 0 & 6 \\
\hline \multirow[t]{2}{*}{ IDEOLOGY } & 2277 & 0.791 & 0.938 & 0 & 2 \\
\hline & \multicolumn{5}{|c|}{ NES 1996} \\
\hline TRADE_OPINION & 846 & 0.524 & 0.491 & 0 & 1 \\
\hline SCHOOLING & 1713 & 13.432 & 2.581 & 0 & 17 \\
\hline GRADUATE & 1711 & 0.099 & 0.299 & 0 & 1 \\
\hline COLLEGE & 1711 & 0.186 & 0.389 & 0 & 1 \\
\hline HIGHER EDUCATION & 1711 & 0.274 & 0.446 & 0 & 1 \\
\hline HIGH SCHOOL & 1711 & 0.315 & 0.465 & 0 & 1 \\
\hline JUNIOR HIGH & 1713 & 0.021 & 0.143 & 0 & 1 \\
\hline AGE & 1712 & 45.529 & 16.853 & 18 & 93 \\
\hline MALE & 1714 & 0.479 & 0.500 & 0 & 1 \\
\hline WHITE & 1704 & 0.852 & 0.355 & 0 & 1 \\
\hline BLACK & 1704 & 0.117 & 0.322 & 0 & 1 \\
\hline INDIAN & 1704 & 0.012 & 0.108 & 0 & 1 \\
\hline ASIAN & 1704 & 0.019 & 0.136 & 0 & 1 \\
\hline TRADE UNION MEMBER & 1687 & 0.120 & 0.325 & 0 & 1 \\
\hline PARTY ID & 1695 & 2.735 & 2.101 & 0 & 6 \\
\hline IDEOLOGY & 1651 & 0.759 & 0.922 & 0 & 2 \\
\hline
\end{tabular}

Note: Cases weighted by respective NES sample weight (v923008 or v960003). 
TABLE A2. Variable descriptions for NES data

\begin{tabular}{|c|c|}
\hline Variables & Coding \\
\hline TRADE_OPINION & $\begin{array}{l}\text { Pro-free trade attitudes: "Some people have suggested placing new limits on foreign } \\
\text { imports in order to protect American jobs. Others say that such limits would raise } \\
\text { consumer prices and hurt American exports. Do you favor or oppose placing new limits } \\
\text { on imports, or haven't you thought much about this?" Coded } 1 \text { if favored new limits; } 0 \text { if } \\
\text { opposed. NES variables v } 923802 \text { and v } 961327 \text {. }\end{array}$ \\
\hline SCHOOLING & Years of full-time education completed. NES variables v923905 and v960607 \\
\hline GRADUATE & $\begin{array}{l}\text { Highest educational attainment dummy: coded } 1 \text { if completed graduate education, and } 0 \\
\text { otherwise. NES variables v923908 and v960610. }\end{array}$ \\
\hline COLLEGE & $\begin{array}{l}\text { Highest educational attainment dummy: coded } 1 \text { if completed college education, and } 0 \\
\text { otherwise. NES variables v923908 and v960610. }\end{array}$ \\
\hline HIGHER EDUCATION & $\begin{array}{l}\text { Highest educational attainment dummy: coded } 1 \text { if completed some higher education } \\
\text { (community or junior college, etc.), and } 0 \text { otherwise. NES variables v923908 and } \\
\text { v960610. }\end{array}$ \\
\hline HIGH SCHOOL & $\begin{array}{l}\text { Highest educational attainment dummy: coded } 1 \text { if completed high school education, and } \\
0 \text { otherwise. NES variables v } 923908 \text { and v } 960610 .\end{array}$ \\
\hline JUNIOR HIGH & $\begin{array}{l}\text { Highest educational attainment dummy: coded } 1 \text { if completed only eight years of } \\
\text { schooling, and } 0 \text { otherwise. NES variables v923905 and v960607. }\end{array}$ \\
\hline AGE & Age in years. NES variables v923903 and v960605. \\
\hline MALE & Gender: coded 1 if male, and 0 if female. NES variables v924201 and v960066. \\
\hline WHITE & $\begin{array}{l}\text { Respondent's race: coded } 1 \text { if White, and } 0 \text { otherwise. NES variables v924202 and } \\
\text { v960067. }\end{array}$ \\
\hline BLACK & $\begin{array}{l}\text { Respondent's race: coded } 1 \text { if Black, and } 0 \text { otherwise. NES variables v924202 and } \\
\text { v960067. }\end{array}$ \\
\hline INDIAN & $\begin{array}{l}\text { Respondent's race: coded } 1 \text { if Indian, and } 0 \text { otherwise. NES variables v924202 and } \\
\text { v960067. }\end{array}$ \\
\hline ASIAN & $\begin{array}{l}\text { Respondent's race: coded } 1 \text { if Asian, and } 0 \text { otherwise. NES variables v924202 and } \\
\text { v960067. }\end{array}$ \\
\hline TRADE UNION MEMBER & $\begin{array}{l}\text { Is respondent currently a trade union member: coded } 1 \text { if yes, and } 0 \text { if no. NES variables } \\
\mathrm{v} 924102 / \mathrm{v} 924101 \text { and } \mathrm{v} 960699 / \mathrm{v} 960698 \text {. }\end{array}$ \\
\hline PARTY ID & $\begin{array}{l}\text { Respondent's party identification: coded from } 0 \text { "strong Democrat" to } 6 \text { "strong } \\
\text { Republican." NES variables v923634 and v960420 }\end{array}$ \\
\hline IDEOLOGY & $\begin{array}{l}\text { Respondent's ideology: coded } 0 \text { if conservative, } 1 \text { if moderate, and } 2 \text { if liberal. NES } \\
\text { variables v923513 \& v960368. }\end{array}$ \\
\hline
\end{tabular}

TABLE A3. Summary statistics for ISSP data

\begin{tabular}{|c|c|c|c|c|c|}
\hline Variables & Observations & Mean & $\begin{array}{l}\text { Standard } \\
\text { deviation }\end{array}$ & Minimum & Maximum \\
\hline PRO-TRADE-DUMMY & 30894 & 0.221 & 0.408 & 0 & 1 \\
\hline AGAINST-TRADE-DUMMY & 30894 & 0.570 & 0.495 & 0 & 1 \\
\hline SCHOOLING & 28022 & 11.375 & 3.713 & 0 & 20 \\
\hline SECONDARY INCOMPLETE & 30294 & 0.218 & 0.413 & 0 & 1 \\
\hline HIGH SCHOOL & 30294 & 0.299 & 0.458 & 0 & 1 \\
\hline COLLEGE & 30294 & 0.230 & 0.421 & 0 & 1 \\
\hline AGE & 30666 & 44.355 & 16.923 & 14 & 98 \\
\hline MALE & 30778 & 0.480 & 0.500 & 0 & 1 \\
\hline CITIZEN & 29440 & 0.973 & 0.163 & 0 & 1 \\
\hline RURAL & 24074 & 1.730 & 0.894 & 1 & 3 \\
\hline PARTY ID & 18352 & 2.905 & 0.979 & 1 & 5 \\
\hline TRADE UNION MEMBER & 24662 & 0.302 & 0.459 & 0 & 1 \\
\hline LN REAL INCOME & 21860 & 9.215 & 1.700 & 2.5 & 13.9 \\
\hline LN GDP PER CAPITA & 30894 & 9.487 & 0.668 & 8.1 & 10.2 \\
\hline
\end{tabular}

Note: Cases weighted by ISSP sample weight. 
496 International Organization

TABLE A4. Variable descriptions for ISSP data

\begin{tabular}{|c|c|}
\hline Variables & Coding \\
\hline PRO-TRADE-DUMMY & $\begin{array}{l}\text { Pro-free trade attitudes: "How much do you agree or disagree with the following } \\
\text { statements: (Respondent's country) should limit the import of foreign products in order to } \\
\text { protect its national economy." Coded } 1 \text { if answered disagree strongly or disagree, and } 0 \\
\text { otherwise. ISSP variable v38. }\end{array}$ \\
\hline AGAINST-TRADE-DUMMY & $\begin{array}{l}\text { Proprotectionism attitudes: same question as above but coded } 1 \text { if answered agree strongly } \\
\text { or agree, and } 0 \text { otherwise. }\end{array}$ \\
\hline SCHOOLING & $\begin{array}{l}\text { Years of full-time education schooling (cap at twenty years). Those with no formal } \\
\text { schooling are coded as } 0 \text {. ISSP variable v204. }\end{array}$ \\
\hline SECONDARY INCOMPLETE & $\begin{array}{l}\text { Highest educational attainment: coded } 1 \text { if incomplete secondary education, and } 0 \\
\text { otherwise. ISSP variable v } 205 \text {. }\end{array}$ \\
\hline HIGH SCHOOL & $\begin{array}{l}\text { Highest educational attainment: coded } 1 \text { if completed secondary education, and } 0 \\
\text { otherwise. ISSP variable v205. }\end{array}$ \\
\hline COLLEGE & $\begin{array}{l}\text { Highest educational attainment: coded } 1 \text { if had college/university education or } \\
\text { semi-higher degrees, and } 0 \text { otherwise. ISSP variable v } 205 \text {. }\end{array}$ \\
\hline AGE & Age in years. ISSP variable v201. \\
\hline MALE & Gender: coded 1 if male, and 0 if female. ISSP variable v200. \\
\hline CITIZEN & $\begin{array}{l}\text { Citizenship: "Are you a citizen of (country)?" Coded } 1 \text { if citizen, and } 0 \text { otherwise. ISSP } \\
\text { variable v63. }\end{array}$ \\
\hline RURAL & Area of residence: coded 1 if urban, 2 if suburban, and 3 if rural. ISSP variable v295. \\
\hline PARTY ID & $\begin{array}{l}\text { Party affiliation: self-placement on a left-right scale. Coded from } 1 \text { "far left" to } 5 \text { "far } \\
\text { right." ISSP variable v } 269 \text {. }\end{array}$ \\
\hline TRADE UNION MEMBER & $\begin{array}{l}\text { Trade union membership: "Are you a member in a trade union at present?" Coded } 1 \text { if } \\
\text { answered "Member now," and } 0 \text { if answered "Not a member now." ISSP variable v268. }\end{array}$ \\
\hline LN REAL INCOME & $\begin{array}{l}\text { Log of real income. Data in local currency converted by PPP conversion factors taken } \\
\text { from World Bank, World Development Indicators. ISSP variable v } 217 \text {. }\end{array}$ \\
\hline LN GDP PER CAPITA & $\begin{array}{l}\text { Log of GDP per capita 1995, PPP (current international dollars). Taken from World Bank, } \\
\text { World Development Indicators. }\end{array}$ \\
\hline
\end{tabular}

\section{References}

Adler, Emanuel. 1992. The Emergence of Cooperation: National Epistemic Communities and the International Evolution of the Idea of Nuclear Arms Control. International Organization 46 (1):101-45.

Allport, G. 1954. The Nature of Prejudice. Reading, Mass.: Addison \& Wesley.

Baker, Andy. 2003. Why Is Trade Reform so Popular in Latin America? World Politics 55 (3):423-55.

Balistreri, Edward J. 1997. The Performance of the Heckscher-Ohlin-Vanek Model in Predicting Endogenous Policy Forces at the Individual Level. Canadian Journal of Economics 30 (1):1-17.

Bauer, Raymond A., Ithiel de Sola Pool, and Lewis Anthony Dexter. 1972. American Business and Public Policy: The Politics of Foreign Trade. 2d ed. Chicago: Aldine-Atherton.

Beaulieu, Eugene. 2002. Factor or Industry Cleavages in Trade Policy? An Empirical Analysis of the Stolper-Samuelson Theorem. Economics and Politics 14 (2):99-131.

Betts, Katherine. 1988. Ideology and Immigration: Australia 1976 to 1987. Melbourne, Australia: Melbourne University Press.

Bhagwati, Jagdish. 1988. Protectionism. Cambridge, Mass.: MIT Press.

Campbell, Angus, Philip E. Converse, Warren E. Miller, and Donald E. Stokes. 1960. The American Voter: Chicago. Chicago: University of Chicago Press.

Case, C. E., A. M. Greeley, and S. Fuchs. 1989. Social Determinants of Racial Prejudice. Sociological Perspectives 32 (4):469-83.

Destler, I. M. 1995. American Trade Politics. 3d ed. Washington, D.C.: Institute for International Economics.

Erikson, Robert S., Norman R. Luttbeg, and Kent L. Tedin. 1991. American Public Opinion: Its Origins, Content, and Impact. 4th ed. New York: Macmillan. 
Finnemore, Martha and Kathryn Sikkink. 1998. International Norm Dynamics and Political Change. International Organization 52 (4):887-917.

Gabel, Matthew J. 1998. Interests and Integration: Market Liberalization, Public Opinion, and European Union. Ann Arbor: University of Michigan Press.

Gleason, J., and L. J. Van Scyoc. 1995. A Report on the Economic Literacy of Adults. Journal of Economic Education 26 (3):203-10.

Goldstein, Judith. 1988. Ideas, Institutions, and American Trade Policy. International Organization 42 (1):179-217.

Goldstein, Judith, and Robert Keohane, eds. 1993. Ideas and Foreign Policy: Beliefs, Institutions, and Political Change. Ithaca, N.Y.: Cornell University Press.

Grossman, Gene, and Elhanan Helpman. 1994. Protection for Sale. American Economic Review 84 (4):833-50.

Haas, Peter M., ed. 1992. Knowledge, Power and International Policy Coordination. Columbia: University of South Carolina Press.

Hall, Peter A., ed. 1989. The Political Power of Economic Ideas. Princeton, N.J.: Princeton University Press.

Hainmueller, Jens, and Michael J. Hiscox. 2004. Educated Preferences: Explaining Individual Attitudes Toward Immigration in Europe. Paper presented at the Annual Meeting of the American Political Science Association, Chicago, September.

Hiscox, Michael J. 2002. International Trade and Political Conflict. Princeton, N.J.: Princeton University Press.

- 2004. Through a Glass and Darkly: Attitudes Towards International Trade and the Curious Effects of Issue Framing. Paper presented at the Annual Meeting of the American Political Science Association, Chicago, September.

Holsti, Ole. R. 1996. Public Opinion and American Foreign Policy. Ann Arbor: University of Michigan Press.

International Social Survey Program (ISSP). 1998. International Social Survey Program: National Identity, 1995 [computer file]. ICPSR release. Koeln, Germany: Zentralarchiv fuer Empirische Sozialforschung/Ann Arbor, Mich.: Inter-University Consortium for Political and Social Research. $\langle$ www.icpsr.umich.edu $\rangle$.

Jones, Ronald. 1971. A Three-Factor Model in Theory, Trade, and History. In Trade, Balance of Payments, and Growth, ed. Jagdish Bhagwati, Ronald Jones, Robert A. Mundell, and Jaroslav Vanek, 3-21. Amsterdam: North-Holland.

Katzenstein, Peter, ed. 1996. The Culture of National Security: Norms and Identity in World Politics. New York: Columbia University Press.

Keck, Margaret E., and Kathryn Sikkink. 1998. Activists Beyond Borders. Ithaca, N.Y.: Cornell University Press.

Kindleberger, Charles. 1975. The Rise of Free Trade in Western Europe. Journal of Economic History 35 (1):20-55.

King, Gary, Michael Tomz, and Jason Wittenberg. 2001. Clarify: Software for Interpreting and Presenting Statistical Results. Version 2.0. Harvard University.

Krugman, Paul A. 1993. What Do Undergrads Need to Know About Trade? American Economic Review 83 (2):23-26.

Magee, Stephen. 1980. Three Simple Tests of the Stolper-Samuelson Theorem. In Issues in International Economics, edited by P. Oppenheimer, 138-53. London: Oriel Press.

Mayda, Anna Maria. 2004. Who Is Against Immigration? A Cross-Country Investigation of Attitudes Towards Immigrants. IZA Discussion Paper No. 1115. Bonn, Germany: Institute for the Study of Labor.

Mayda, Anna Maria, and Dani Rodrik. 2005. Why Are Some People (and Countries) More Protectionist than Others? European Economic Review. 49 (6):1393-430.

McClosky, Herbert, and Alida Brill. 1983. Dimensions of Tolerance: What Americans Believe About Civil Liberties. New York: Russell Sage Foundation.

Miller, Warren E., Donald R. Kinder, Steven J. Rosenstone, and the National Election Studies. American National Election Study, 1992: Pre- and Post-Election Survey [Enhanced with 1990 and 1991 
Data] [computer File]. 2d. ICPSR ed. Ann Arbor: University of Michigan, Center for Political Studies, and Inter-University Consortium for Political and Social Research. 〈www.icpsr.umich.edu〉.

Mussa, M. 1974. Tariffs and the Distribution of Income. Journal of Political Economy 82 (6):1191-203. O'Rourke, Kevin, and Richard Sinnott. 2002. The Determinants of Individual Trade Policy Preferences. In Brookings Trade Forum, edited by Susan M. Collins and Dani Rodrik, 157-96. Washington, D.C.: Brookings Institution.

Panel Study of Income Dynamics. 1999. 1968-1980 Retrospective Occupation-Industry Files Documentation. Ann Arbor: Survey Research Center, University of Michigan.

Price, Richard. 1998. Reversing the Gun Sights: Transnational Civil Society Targets Land Mines. International Organization 52 (3):613-44.

Pryor, Frederic. 2002. General Discussion. In Brookings Trade Forum, edited by Susan M Collins and Dani Rodrik, 201-3. Washington, D.C.: Brookings Institution.

Rogowski, Ronald. 1989. Commerce and Coalitions. Princeton, N.J.: Princeton University Press.

Rosenstone, Steven J., Donald R. Kinder, Warren E. Miller, and the National Election Studies. American National Election Study, 1996: Pre- and Post-Election Survey [Computer file]. 4th version. Ann Arbor: University of Michigan, Center for Political Studies [producer], 1999. Ann Arbor, MI: Interuniversity Consortium for Political and Social Research [distributor], 2000.

Ruggie, John Gerard. 1998. What Makes the World Hang Together? International Organization 52 (4):855-85.

Sass, Steven. 1997. The Promise of Private Pensions. Cambridge, Mass.: Harvard University Press.

2003. Reforming the U.S. Retirement Income System: The Growing Role of Work. Issues in Brief No. 1; Boston College, Mass.: Center for Retirement Research.

Saunders, P. 1980. The Lasting Effects of Introductory Economics Courses. Journal of Economic Education 12 (1):1-14.

Scheve, Kenneth F., and Matthew J. Slaughter. 2001a. What Determines Individual Trade-Policy Preferences? Journal of International Economics 54 (2):267-92.

- 2001b. Globalization and the Perceptions of American Workers. Washington, D.C.: Institute for International Economics.

. 2001c. Labor Market Competition and Individual Preferences over Immigration Policy. Review of Economics and Statistics 83 (1):133-145.

Sikkink, Kathryn. 1993. Human Rights, Principled Issue-Networks, and Sovereignty in Latin America. International Organization 47 (3):411-42.

Social Security Administration. 2002. 2000 Income of the Aged Chartbook. Washington, D.C.: Government Printing Office.

Stolper, W., and P. Samuelson. 1941. Protection and Real Wages. Review of Economic Studies 9 (1):58-73.

Walstad, William B., and Ken Rebeck. 2002. Assessing the Economic Knowledge and Economic Opinions of Adults. Quarterly Review of Economics and Finance 42 (5):921-35.

Walstad, William B. 1997. The Effect of Economic Knowledge on Public Opinion of Economic Issues. Journal of Economic Education 28 (3):195-205.

Wendt, Alexander. 1999. Social Theory of International Politics. Cambridge: Cambridge University Press.

World Bank. Various years. World Development Indicators. Washington, D.C.: World Bank.

Zaller, John. 1992. The Nature and Origins of Mass Opinion. New York: Cambridge University Press. 